\title{
Chondrogenesis of Adipose-Derived Stem Cells with Chondrocytes in Low Serum towards Clinical Application
}

(Sel Asal Kondrogenesis Terbitan Adipos dengan Kondrosit dalam Serum Rendah untuk Penggunaan Klinikal)

\author{
Adila A Hamid*, Satish VAarman Jeyabalan, AleZa OMar, NiK ZatTil HANAn Mohd Yasin, \\ WONG TZENG LIN, LIAU LING LING, NUR AZURAH ABDUL GHANI, \\ ANEEZA KHAIRIYAH WAN HAMIZAN \& CHUA KIEN HUI
}

\begin{abstract}
Currently, fetal bovine serum (FBS) have been widely use in culture media to promote human cell proliferation. However, the usage of FBS for cell therapy in clinical application was associated with the risk of viral and prion transmission as well as immune rejection. To provide an option for this risk, this study was conducted to determine the effect of adipose derived stem cells (ADSCS) co-culture with chondrocyte in promoting cell proliferation and chondrogenesis toward FBS free condition. ADSCS co-cultured with chondrocyte at the ratio of 1:1, 2:1 and 1:2 were tested. Cell morphology changes, cell proliferation and gene expression level of stemness (Oct4, FGF-4, Nanog) and chondrogenic (Collagen Type II, ACP) were assessed. The results showed ADSCs in all co-culture groups changed morphology from fibroblastic spindle to polygonal shape which resembled chondrocytes. The morphological changes were accompanied with increased expression of chondrogenic genes; denoted chondrogenesis process. While maintaining expression of stemness genes indicated continuation of cell proliferation. From the three co-culture groups tested; ADSCs and chondrocytes (1:1 ratio) have been shown to exert better effects in promoting cell proliferation and chondrogenesis. In conclusion, ADSCs could replace FBS to grow sufficient number of chondrogenic cells to repair cartilage injury in the near future. Further in vivo study should be performed to test the effectiveness of this co-culture technique in cartilage injury repair.
\end{abstract}

Keywords: Cartilage; chondrocyte; clinical application; serum; stem cell

ABSTRAK

Pada masa kini, serum fetus bovin (FBS) telah digunakan secara meluas di dalam media kultur sebagai faktor penggalak pertumbuhan sel. Namun begitu, penggunaan FBS untuk terapi sel secara klinikal dikaitkan dengan risiko transmisi virus dan prion serta tolakan imun. Bagi menangani risiko ini, kajian ini dijalankan bagi menentukan kesan ko-kultur sel stem adipos (ADSCS) dan kondrosit terhadap proliferasi sel dan kondrogenesis kearah kondisi pengkulturan bebas FBS. ADSCS dikultur bersama kondrosit dengan nisbah 1:1, 1:2 dan 2:1 telah diuji. Perubahan morfologi sel, proliferasi sel dan ekspresi gen kesteman (Oct4, FGF-4, Nanog) dan gen kondrogenik (kolagen jenis II dan ACP) telah dinilai. Keputusan kajian mendapati ADSCs dalam semua kumpulan ko-kultur berubah morfologi daripada bentuk fibroblas memanjang kepada bentuk poligon yang menyerupai kondrosit. Perubahan bentuk ini turut disertai dengan ekpresi gen kondrogenik yang meningkat, ini menandakan proses kondrogenesis telah berlaku. Sementara itu, ekspresi gen kesteman memberi penunjuk bahawa proliferasi sel dapat diteruskan. Daripada tiga kumpulan kajian nisbah ko-kultur yang dikaji; ADSCs bersama kondrosit (1:1 ratio) telah menunjukkan kesan yang lebih ketara dalam menggalakkan proliferasi sel dan kondrogenesis. Kesimpulannya, ADSCs berpotensi menggantikan FBS sebagai faktor pertumbuhan bagi menyediakan jumlah kondrosit yang mencukupi untuk merawat kecederaan rawan pada masa hadapan. Kajian seterusnya di dalam model in vivo perlu dijalankan bagi menguji keberkesanan teknik ko-kultur ini bagi merawat kecederaan rawan.

Kata kunci: Kondrosit; penggunaan klinikal; rawan; sel asal; serum

\section{INTRODUCTION}

Serum has been widely used as supplement in cell culture media and it is essential for cell attachment, growth, metabolism and acts as a buffering agent to maintain the $\mathrm{pH}$ of cell culture media. The most commonly used serum to support cell growth is derived from animals, mainly from bovine fetus. Fetal bovine serum (FBS) contains components such as proteins, growth factors, trace elements and hormones that are necessary for cell proliferation and maintenance of cells physiology (Valk et al. 2010). Despite the known advantages of serum in cell culturing media, there are a few drawbacks associated with the use of serum especially from animal sources. First of all, increased utilisation of fetal bovine serum for routine cell culture works worldwide demands more bovine fetuses to be sacrificed and the collection of serum may cause suffering for the unborn calf (Brunner et al. 2010; Valk et al. 2004). Secondly, fetal bovine serum may also be 
the possible source of xenogeneic contaminations in cell culture such as contamination of virus and prion. In fact, 20 to $50 \%$ of commercial FBS was reported related to virus contamination (Wessman \& Levings 1999). In addition, bovine protein could also attach to cells in culture and acts as antigenic substances that induce immunological reactions during transplantation (Ferdinando \& Gaetana 2007). Thirdly, there are batch to batch variations that compromised the quality of the serum hence testing is necessary to maintain the quality of each batch for cell culture. As a result, phenotypical differences might occur in the cell culture leading to inconsistency of the data or the final products (Valk et al. 2010). These limitations hinder the clinical application of cells that is cultured in media contain serum and signify the demand of safer and more reliable method to replace the serum. The potential replacement of FBS by stem cells will be discussed in this study.

Stem cells, widely known for their self-renewal and wide differentiation potentials represent a viable alternative for tissue regeneration (Tapp et al. 2009). The discovery of stem cells residing in human adipose tissue has drawn attention to the tissue engineering field and offers novel tools to treat various diseases, such as autoimmune-induced diseases (Gonzalez-Rey et al. 2010), multiple sclerosis (Riordan et al. 2009), treatment of fistulas in Crohn's disease (García-Olmo et al. 2005) and potential for microtia repair (Goh et al. 2017). The initial method to isolate cells from adipose tissue were introduced by Rodbell et al. (1960) and the isolation yielded two populations of cells, the floating mature adipocytes and stromal vascular fractions (SVF). The stromal vascular fraction includes heterogeneous cell population, including preadipocytes, fibroblasts, smooth muscle cells, lymphocytes, macrophages, endothelial cells and adipose derived stem cells (ADSCS). The ADSCs that are isolated from adipose tissue possess high proliferative capability (Zuk et al. 2002) and can undergo various differentiation pathways, including osteogenic (Grottkau \& Lin, 2013), adipogenic (Turner et al. 2017), chondrogenic (Hamid et al. 2012), neurogenic (Zhao et al. 2015), smooth muscle (Salah et al. 2013) and insulin-producing cells (Mohamad Buang et al. 2012). In addition, ADSCs have been shown to enhance the recovery of injured human hepatocellular carcinoma (HepG2) through secretion of Hepatocyte Growth Factor (HGF) and Vascular Endothelial Growth Factor (VEGF) (Liau et al. 2018). As one of the most promising stem cells population identified, ADSCs offers two main advantages over other types of stem cells such as bone marrow stem cell and embryonic stem cells. Firstly, ADSCs can be harvested in large quantities with little donor site morbidity during subcutaneous liposuction procedure. Secondly, ADSCs eliminate ethical concerns associated with the usage of embryonic stem cells because they can be derived from autologous fat (Cawthorn et al. 2012).

In the light of increasing aging population worldwide, people are more susceptible to the musculoskeletal disorders such as osteoarthritis (OA), rheumatoid arthritis (RA), low back pain (LBP) and neck pain (NP) (Woolf 2015). Osteoarthritis, the most common form of arthritis, involves inflammation and major structural changes of the joint which causes pain and functional disability (Cross et al. 2014). As a result, enormous costs for health and social care systems are involved in managing osteoarthritis patients. In Asia, it has been estimated that the percentage of people aged 65 years will increase from $6.8 \%$ in 2008 to $16.2 \%$ in 2040 (Fransen et al. 2011). Since OA has a strong relationship with ageing, the above-mentioned figure is of concern as it is indirectly reflected the impairment of life quality among the elderly affected with osteoarthritis. Furthermore, the recovery of cartilage lesion in osteoarthritis remains challenging because cartilage tissue has a very limited capacity for intrinsic healing. This is due to poor vascularisation, low chondrocyte density and poor mobility of chondrocytes (Wang et al. 2017).

Autologous chondrocytes implantation (ACI) is a procedure that has shown promising outcomes for articular cartilage regeneration in early clinical studies (Breinan et al. 1997; Nehrer \& Minas 2000). For ACI, autologous chondrocytes are harvested arthroscopically from nonweight-bearing area of the articular cartilage and grown in monolayer cell culture to larger numbers in vitro. Once sufficient numbers are reached, cultured chondrocytes suspension is injected into the articular defect which is then covered by a periostal flap or collagen membrane (Afizah et al. 2007). The effectiveness of ACI have been shown previously by a long-term study of Brittberg et al. (1994) and Brittberg (1999) and this procedure can be modified with incorporation of biodegradable material with autologous chondrocytes in vitro before being implanted to the patients. Despite the clinical effectiveness of ACI, the procedure has been associated with significant donor-site morbidity, a slow rate of chondrocyte proliferation (Nejadnik et al. 2010) and difficulty in obtaining an adequate number of chondrocytes. To achieve a sufficient number of chondrocytes for ACI, the cells need to be expanded in a monolayer condition. However, chondrocytes that are released from the cartilage matrix and placed in monolayer culture dedifferentiate to fibroblast-like state and have a tendency to lose their chondrocyte-specific phenotypes (Benya \& Shaffer 1982; Domm et al. 2002; Schnabel et al. 2002). Dedifferentiation of chondrocyte in monolayer culture is accompanied by morphological changes and collagen expression profiles (Fuss et al. 2000; Stewart et al. 2000) and can occur as early as in the first passage (Schulze-Tanzil et al. 2002). This occurrence may limit the chondrocyte expansion and proliferation in an attempt to treat big lesions through ACI procedure.

Previous studies have proven that co-culture technique may provide environment that is necessary for stem cell differentiation and promote chondrocyte proliferation. The studies have primarily utilised bone marrow derived stem cells and to a lesser extent, adipose-derived stem 
cell (Waters et al. 2013). In most cases, 10\% FBS along with growth factors including transforming growth factor (TGF) $\beta 1$ and $\beta 3$, basic fibroblast growth factor (bFGF), bone morphogenic protein-6 (BMP-6), dexamethasone were supplemented in the growth media during cell culturing to enhance chondrogenic differentiation (Bahney et al. 2011; Waters et al. 2013). However, little is known about the potential of ADSCs in co-culture environment to replace FBS as a source of growth factors to promote cell proliferation of chondrocyte in vitro.

In the present study, chondrocytes and adipose derived stem cells (ADSCS) with 1:1, 1:2 and 2:1 ratio were cocultured in order to evaluate if ADSCs could replace FBS as growth factor in culturing medium. The aim of this study was to answer the following research questions: Can ADSCs replace FBS as commonly used growth factors and lead to increase proliferation of chondrocytes in coculture system? Do different co-cultures ratio of ADSCs and chondrocyte influence cell proliferation and chondrogenic markers expression? The outcome of this study should provide a better understanding of the effect of ADSCs in chondrogenic co-culture system in minimal effect of FBS as a strategy to improve proliferation of chondrocytes in vitro towards clinical application.

\section{MATERIALS AND METHODS}

\section{ETHICS STATEMENT}

Abdominal subcutaneous tissue was collected from consented patient undergoing caesarean section in the Department of Obstetrics and Gynaecology, Universiti Kebangsaan Malaysia Medical Centre. Cartilage was collected from patients undergoing nasal septoplasty procedure in the Department of Otorhinolaryngology, Universiti Kebangsaan Malaysia Medical Center. Sample collection and research protocols were reviewed and approved by the Universiti Kebangsaan Malaysia Medical Research and Ethics committee (FF-068-2013).

\section{ISOLATION OF ADIPOSE DERIVED STEM CELLS (ADSCS) ISOLATION}

Adipose tissue was collected in a sterile container and processed for stem cell isolation within $30 \mathrm{~min}$ of sample collection. Tissues were washed three times with phosphate-buffered saline (PBS; pH7 .2; Invitrogen, Grand Island, USA) and minced into smaller pieces. The tissue was digested in $0.3 \%$ collagenase type I (Worthington, Lakewood, NJ) and placed in orbital shaker at $37^{\circ} \mathrm{C}$ with continuous agitation. After centrifugation, the supernatant containing mature adipocytes, was discarded and the cell pellet was suspended in culture medium (Ham's F12: Dulbecco's Modified Eagle Medium (F12: DMEM) supplemented with 10\% FBS (Invitrogen), 1\% Vitamin C (Sigma, St. Louis, MO) 1\% antibiotic-antimycotic (Invitrogen), 1\% Glutamax (Invitrogen) and plated immediately in T25 flasks. This initial passage of the primary cell culture was referred to as passage $0(\mathrm{P} 0)$.
Cultures were maintained in an incubator with $5 \% \mathrm{CO}_{2}$ at $37^{\circ} \mathrm{C}$. Cells were passaged repeatedly after achieving a density of $75 \%-90 \%$ (approximately 4 days in culture) until passage 4 .

\section{FLOW CYTOMETRY ANALYSIS}

For ADSCs characterisation, cell surface antigen phenotyping was performed on ADSCs at passage 4. The cells were incubated with anti-human antibodies: CD9phycoerythrin (PE), CD34-fluorescein isothiocyanate (FITC), CD117-PE, CD31-PE, CD44-FITC, CD-45-FITC, CD73-FITC, CD90-FITC, HLA ABC-FITC and HLA DP-DQ-DR-FITC (BD Biosciences, NJ, USA). Approximately 10,000 labeled cells were acquired for each surface marker and the data were analyzed using CELLQuestPro acquisition software (BD Bioscience, Franklin Lakes, NJ, USA).

\section{ISOLATION OF CHONDROCYTES}

The collected cartilage was cleaned by removing the adhering soft connective tissue and bone segment using phosphate buffer saline (PBS). Then, the cartilage was minced into smaller pieces and placed in $0.6 \%$ Collagenase Type II buffer for $3-4 \mathrm{~h}$ in a $37^{\circ} \mathrm{C}$ shaker incubator. Subsequently, the cell pellet was harvested after repeated centrifugation and rinsed with PBS. Finally, the pellet was suspended in Ham's F12: Dulbecco's Modified Eagle Medium (F12:DMEM) supplemented with 10\% FBS and 2 $\mu \mathrm{L}$ of Insulin Transferrin Selenium (ITS) and transferred into a 6-well plate. The culture was maintained in a humidified incubator with $5 \% \mathrm{CO}_{2}$ at $37^{\circ} \mathrm{C}$. After reaching $90 \%$ confluence, the primary culture (P0) was trypsinised using $0.125 \%$ trypsin-EDTA and passaged at a culture expansion ratio of 1:3 until passage $1(\mathrm{P} 1)$.

\section{CELL LABELLING}

To observe the morphological features of the cells, chondrocytes and adipose derived stem cells were detached using $0.125 \%$ Tripsin EDTA and $1.5 \mathrm{uL}$ of 10 $\mathrm{mM}$ CellTracker ${ }^{\mathrm{TM}}$ (Invitrogen) dye, CellTracker ${ }^{\mathrm{TM}}$ Green CMFDA (5-chloromethylfluorescein diacetate) for chondrocytes and CellTracker ${ }^{\mathrm{TM}}$ Red CMTPX for hADSCs were added.

\section{CO-CULTURE OF ADSCS WITH CHONDROCYTES}

ADSCs and chondrocytes were seeded onto a 24-well plate at a respective ratio (Table 1 ) to yield $9 \times 10^{4}$ cells/well and cultured with Ham's F12: DMEM media supplemented with $1 \%$ FBS.

\section{TOTAL CELL NUMBER DETERMINATION}

To determine total cell number all co-cultures group were trypsinised using $0.125 \%$ Trypsin EDTA and the cell number were determined using haemacytometer and Trypan Blue dye exclusion. 
TABLE 1. Mixture ratio of ADSCs and chondrocyte

\begin{tabular}{ccc}
\hline & ADSCs & Chondrocytes \\
\hline Control & $9 \times 10^{4}$ & - \\
$1: 2$ & $3 \times 10^{4}$ & $6 \times 10^{4}$ \\
$1: 1$ & $4.5 \times 10^{4}$ & $4.5 \times 10^{4}$ \\
$2: 1$ & $6 \times 10^{4}$ & $3 \times 10^{4}$ \\
Control & - & $9 \times 10^{4}$ \\
\hline
\end{tabular}

\section{RNA EXTRACTION}

Total RNA was extracted from all co-culture groups at day 5 using TRI-Reagent (Molecular Research Centre, USA) in accordance with manufacturer's instruction. About five $\mathrm{mL}$ of polyacryl carrier (Molecular Research Centre, USA) was added to precipitate the total RNA. The RNA pellet was washed with $75 \%$ ethanol and dried before dissolving in DNase- and RNase- free distilled water (Invitrogen). The total RNA yield and integrity was determined by spectrophotometer (Bio-Rad, USA). The extracted RNA was immediately stored at $-80^{\circ} \mathrm{C}$ until further analysis.

\section{CDNA SYNTHESIS}

Approximately $5 \mu \mathrm{L}$ of total RNA from co-culture cells was used to synthesise cDNA using Superscript_ III FirstStrand Synthesis kit (Invitrogen) which contained reverse transcriptase enzyme mix, 2_ RT reaction mix and $E$. coli RNase $\mathrm{H}$. The reaction was conducted according to instruction from the manufacturer. The protocol conditions used were $10 \mathrm{~min}$ at $23^{\circ} \mathrm{C}, 60 \mathrm{~min}$ at $42^{\circ} \mathrm{C}$, and $10 \mathrm{~min}$ at $94^{\circ} \mathrm{C}$. The synthesised cDNA was used as a template to perform qPCR to assess the expression level of the stemness genes (Oct-4, FGF-4, Nanog) and chondrogenic genes (Collagen Type II and ACP).
QUANTITATIVE GENE EXPRESSION ANALYSIS BY REALTIME POLYMERASE CHAIN REACTION (qPCR)

To determine the mRNA expression of chondrogenic and stem cell associated markers, the cDNA was subjected to quantitative PCR analysis using $\mathrm{IQ}^{\mathrm{TM}} \mathrm{S} Y \mathrm{BR}^{\circledR} \mathrm{Green}$ Supermix (Bio-Rad, Hercules,CA). The sets of primer used to study the gene of interest were Collagen Type II (Col II), Aggrecan Core Protein (ACP), Nanog homeobox pseudogene 3 (Nanog3), Octamer Binding Protein (Oct-4) and Fibroblast Growth Factor (FGF-4) (Table 1). Glyceraldehyde-3-phosphate dehydrogenase (GAPDH was used as the housekeeping gene to normalise the data. The specific primers were designed using Primer 3 software according to published GeneBank database sequences. The quantitative PCR reaction was performed using SYBR Green as a dye to detect PCR products in BioRad iCycler PCR machine. The reaction mixture consisted of iQ SYBR Supermix, forward and reverse primers (500 nM each), deionised water and the respected cDNA. The reactions were performed under following conditions:

Cycle 1: Step $195^{\circ} \mathrm{C}$ for 3 min (1 time), cycle 2: Step $195^{\circ} \mathrm{C}$ for $10 \mathrm{~s}$ and $\mathrm{Step} 261^{\circ} \mathrm{C}$ for $30 \mathrm{~s}$ (40 times), cycle 3: Step $195^{\circ} \mathrm{C}$ for $1 \mathrm{~min}$ (1 time), cycle 4: Step $155^{\circ} \mathrm{C}$ for $1 \mathrm{~min}(1 \mathrm{time})$ and cycle 5: Step $160^{\circ} \mathrm{C}$ for $10 \mathrm{~s}(70$ times). To verify the specificity of each PCR product, gel electrophoresis analysis was performed. Each PCR products was subjected to $2 \%$ agarose (Invitrogen, Carlsbad, CA, USA) gel electrophoresis stained with ethidium bromide (Sigma-Aldrich, St. Louis, MO, USA) and visualised using UV transillumination (Vilber Lourmat, Marne La Vallee, France).

\section{STATISTICAL ANALYSIS}

Data were analysed using SPSS 15.0 (SPSS Inc. Chicago, IL, USA) and presented as mean \pm standard error of mean (SEM) and standard deviation (SD). One-way ANOVA statistical analysis was performed using GraphPad Prism version 7 (La Jolla California USA) and a difference at the 5\% level was considered as a statistically significance.

TABLE 2. List of primers used in quantitative polymerase reaction chain (qPCR)

\begin{tabular}{|c|c|c|c|}
\hline Gene & Acession no. & Primer sequences $\left(5^{\prime}, \ldots . .3^{\prime}\right)$ & Product size (bp) \\
\hline GAPDH & NM_002046 & $\begin{array}{l}\text { F: tcc ctg agc tga acg gga ag } \\
\text { R: gga gga gtg ggt gtc gct gt }\end{array}$ & 217 \\
\hline COL II & NM_001844 & $\begin{array}{l}\text { F: cta tct gga cga agc agc tgg ca } \\
\text { R: atg ggt gca atg tca atg atg g }\end{array}$ & 209 \\
\hline $\mathrm{ACP}$ & NM_001135 & $\begin{array}{l}\text { F:cac tgt tac cge cac ttc cc } \\
\text { R: acc agc gga agt cec ctt cg }\end{array}$ & 118 \\
\hline NANOG & NM_024865.2 & $\begin{array}{l}\text { F: ctg tga ttt gtg ggc ctg aa } \\
\text { R: tgt ttg cct ttg gga ctg gt }\end{array}$ & 153 \\
\hline FGF-4 & NM_002007 & $\begin{array}{l}\text { F: gat gag tgc acg ttc aag ga } \\
\text { R: ggt tcc cet tct tgg tct tc }\end{array}$ & 118 \\
\hline OCT-4 & NM_002701 & $\begin{array}{l}\text { F: 5'-aag gat gtg gtc cga gtg tg-3' } \\
\text { R: 5'-gaa gtg agg gct ccc ata gc-3 }\end{array}$ & 180 \\
\hline
\end{tabular}




\section{RESULTS AND DISCUSSION}

Normal growth media often contain $2-10 \%$ of serum for growth and maintenance of cells. Although FBS has been widely used as growth supplementation to promote cell proliferation, the use of FBS is controversial for a number of reasons particularly with regards to safety and efficacy of cells that are cultured in the presence of FBS. Hence, in this study we reported the feasibility of ADSCs to replace serum in co-culture model to enhance cell proliferation of chondrocytes in vitro. Although $10 \%$ of FBS was used at the initial stage of ADSCs culture, the FBS concentration were reduced to $1 \%$ for cell attachment in the culture media used during co-culture. For a clinical application, the $10 \%$ FBS for initial cultivation of ADSCs are easily replaceable with the currently available serum free culture media. While, the low FBS concentration (1\%) used during co-culture of ADSCs and chondrocyte can be replaced with $1 \%$ autologous human serum for autologous application. Human serum is a better alternative for cell culture because it is economical, safer and easily available. Human serum has been shown to promote ADSCs proliferation (Hui et al. 2012), bone marrow derived stem cell growth (Shahdadfar et al. 2005) and promote engraftment after allogenic transplantation of human peripheral blood haematopoetic stem cells in NOD/SCID mice (Kim et al. 2005). In our study, ADSCs is characterised by flow cytometry analysis. ADSCs displayed positive staining for stromal associated markers (CD90- 99.9\%, CD73-99.7\%, CD44-99.4\%), stem cell adhesion molecule (CD9-91.2\%) and MHC class I (HLA ABC-91.2\%). On the contrary, ADSCs lacking expression of haematopoietic markers (CD31-1.9\%, CD45-6.3\%), stem cell factor (CD117-2.4\%) and histocompatibility antigen class II (HLA DP-DQ-DR-3.0\%).

\section{EFFECTS OF CO-CULTURE OF ADSCS WITH CHONDROCYTES ON CELL PROLIFERATION}

The results from our study indicated that, the co-culture of chondrocytes with ADSCs promoted cell proliferation in all co-culture ratio groups as compared to the chondrocytes alone. On day 5 of culture, the cell numbers were significantly higher in all ADSCs and chondrocyte co-culture groups as compared to ADSCs and chondrocytes alone. The cells showed highest proliferation in co-culture group of $1: 1$ and $1: 2$. While the co-culture group showed the least cell proliferation was in group of 2:1. Statistical analysis showed significant difference of cell proliferation between the co-culture groups of 1:1,1:2 and 2:1 when compared with control groups (chondrocytes and ADSCs) $(p<0.05)$. However, there was no significant difference in the cell proliferation between all co-culture groups (Figure 2). The effects might be due to soluble factors, VEGF, HIF-1 $\alpha$, IGF-1 and fibroblast growth factor that were secreted by ADSC as confirmed by a previous study (Zhong et al. 2016). Using co-culture model, Kim et al. (2007) reported that ADSCs promoted human dermal fibroblast proliferation by cell-to cell contact as well as paracrine activation. One dimensional gel electrophoresis combined with tandem mass spectrometry analysis showed that ADSCs secreted growth factors, collagen and fibronectin that are important for cell growth and proliferation (De Lany et al. 2005; Kratchmarova et al. 2002). Findings from these studies were in consistent with the term 'trophic' that has been introduced by Caplan and Dennis (2006) in describing the factors secreted by mesenchymal stem cells. This term is also associated with the effect of the factors produced by mesenchymal cells in supporting in the proliferation and matrix production of neighbouring cells

\section{EFFECT OF CO-CULTURE OF ADSCS WITH CHONDROCYTE ON CHONDROGENESIS AND STEMNESS GENE EXPRESSION}

Despite the suggested trophic effect of ADSCs that helps in cell proliferation, we did not exclude the possible influence of chondrocytes in promoting ADSCs differentiation. In the presence of chondrocytes, ADSCs are directed into chondrogenic differentiation demonstrated by the morphological changes of ADSCs from the initial fibroblastic like cells to polygonal like cells that resemble chondrocytes. Cell morphology of control (ADSCs and chondrocytes only) and co-culture groups were assessed

\section{Total Cell Number at Day 5}

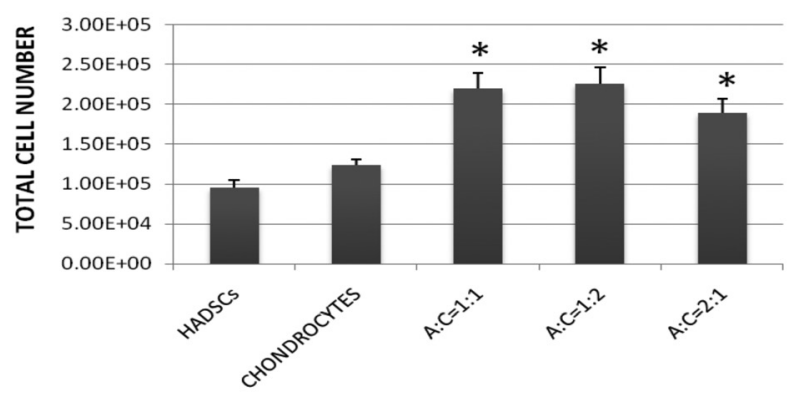

FIGURE 1. Histogram showing the total cell number at day 5 of control (adipose derived stem and co-culture groups. Adipose derived stem cells (ADSCs) were cultured with chondrocytes in 1:1, $1: 2$ and $2: 1$ ratio. Results showed as mean \pm SEM of three independent experiments. $* p<0.05$ 
under inverted and fluorescence microscope on day 1, 3 and 5 (Figures 2-5). In a monolayer culture, ADSCs exhibit fibroblastic-shape feature while chondrocytes exhibit polygonal-shaped throughout day 1, 3 and 5 of culture (Figures $2 \& 3$ ). In co-culture groups with a ratio of 1:1 and 1:2, some of the ADSCs that were initially spindle shape (red-stained) have changed into polygonal shaped cells. These morphological changes can be particularly seen at day 3 and 5 in the co-culture group with a ratio of 1:1 and 1:2 (Figure 5). The morphological changes were accompanied by expression of chondrogenic specific markers (Collagen Type II and ACP) in all co-culture groups. In order to assess the effect of co-culture ratios on mRNA expression level of chondrogenic markers, qPCR was performed on Collagen Type II and Aggrecan core protein (ACP). Cells cultured in a co-culture group expressed chondrogenic specific marker, Col II and ACP at day 5 . Between all co-culture groups, group with a ratio of 1:1 showed higher expression of Collagen Type II while group with a ratio of 1:2 showed higher expression of ACP. However, there was no statistically difference of Collagen Type II and ACP expression between all co-culture groups $(1: 1,1: 2,2: 1)$ with control (chondrocytes) (Figure 6). Collagen Type II and aggrecan are specific markers for regenerated cartilage (Anderer \& Libera 2002; Schulzetanzil 2009) and the expression of these markers are significant to differentiate between hyaline cartilage and fibrocartilage. Fibrocartilage may function satisfactorily in cartilage repair for a certain period of time, however it does not exhibit normal articular material property. As a result, the repair will be less durable to withstand loading than normal articular cartilage (Frenkel SR \& Di Cesare 1999). Our results indicated that chondrocytes may exert some effects in promoting chondrogenic differentiation of ADSCs. Previous studies done using mesenchymal stem cells showed similar results when mesenchymal stem cells were cultured together with chondrocytes (Yang et al.2012; $\mathrm{Xu}$ et al. 2013). Interestingly, co-culture group cells also expressed stem cell associated markers, Oct-4, Nanog and FGF-4. In all co-culture groups, the expression of Oct-4, FGF-4, and Nanog were relatively low as compared to ADSCs alone (Figure 6). The expression of stem cell associated markers gave the implication that there was still stemness property exhibited by ADSCs although in a co-cultured environment that favours chondrogenesis. We believed with the extension of culturing period, there was a possibility that the remaining ADSCs in the co-culture could be differentiated into chondrogenic lineage. But the most important part that contributed to the success of the co-culture system is the ideal ratio of both cells. An ideal ratio should yield high quality cartilage as well as to minimize the usage of fetal bovine serum in cultures. In the present data, group ratio of 1:1 (ADSCs: chondrocytes) has greater effect on cell proliferation and chondrogenic gene expression as compared to other groups. Viable chondrocyte is very difficult to be obtained from the patient cartilage and if successful, only a small number of chondrocyte can be harvested. In the ratio of 1:1 (ADSCs: chondrocytes), less number of chondrocytes is needed to start the culture. Although a ratio of co-culture 1:2 showed almost similar outcome, there was possibility that the expression of high stemness marker as indicated in FGF-4
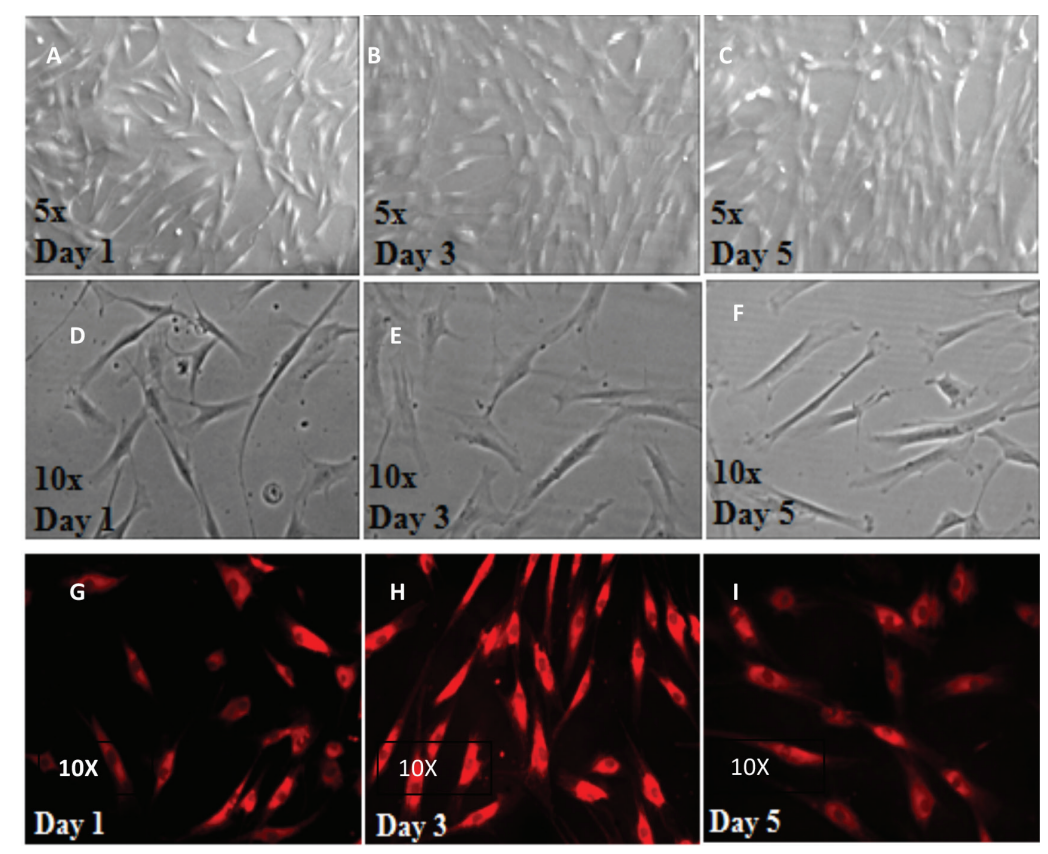

FIGURE 2. Cell morphology of adipose derived stem cells (ADSCs) were assessed under inverted and fluorescence microscope on day 1,3 and 5. Morphology of ADSCs at day 1,3 and 5 under bright field (A-F) and cell tracker labelled ADSCs as indicated by red-stained cells (G-I). As early as day 1, the adherent ADSCs grew into spindle shaped cells and the cell phenotype remains up to day 5 . The ADSCs reached $90 \%$ of confluence at 5 th day of culture (A-C) 

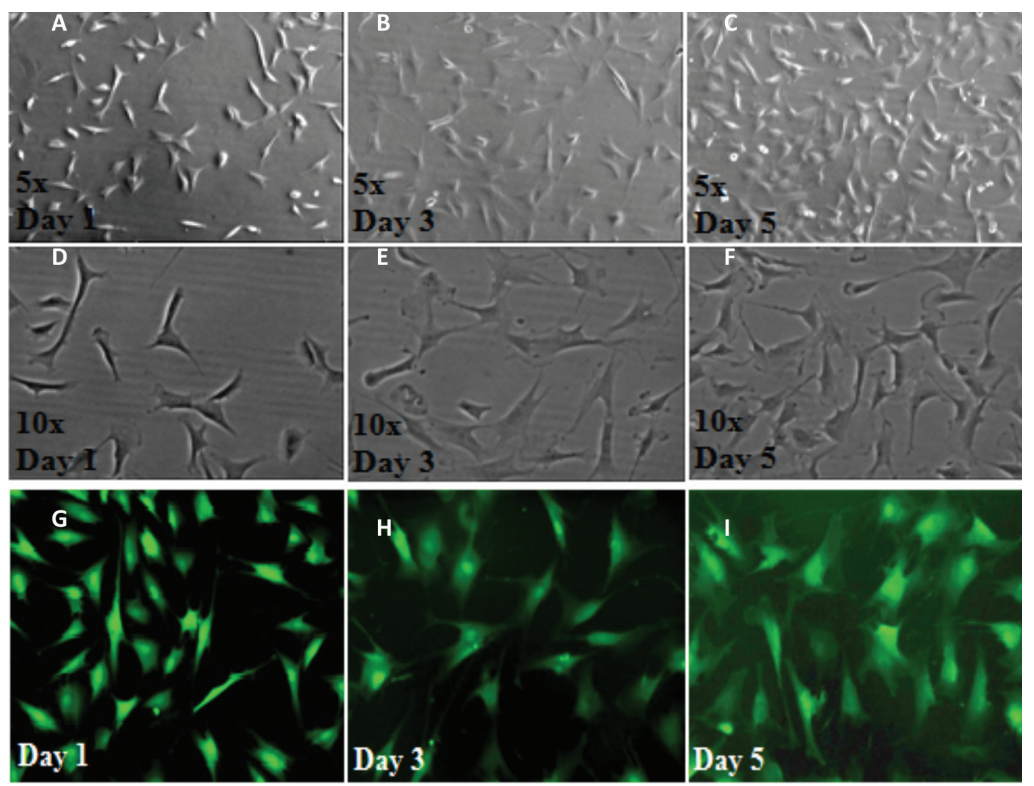

FIGURE 3. Morphology of chondrocytes from nasal septum cultured in vitro. Primary polygonal nasal septum chondrocytes were grown at day 1,3 and 5 under bright field (A-F) and cell tracker labelled chondrocytes as indicated by green-stained cell (G-I)
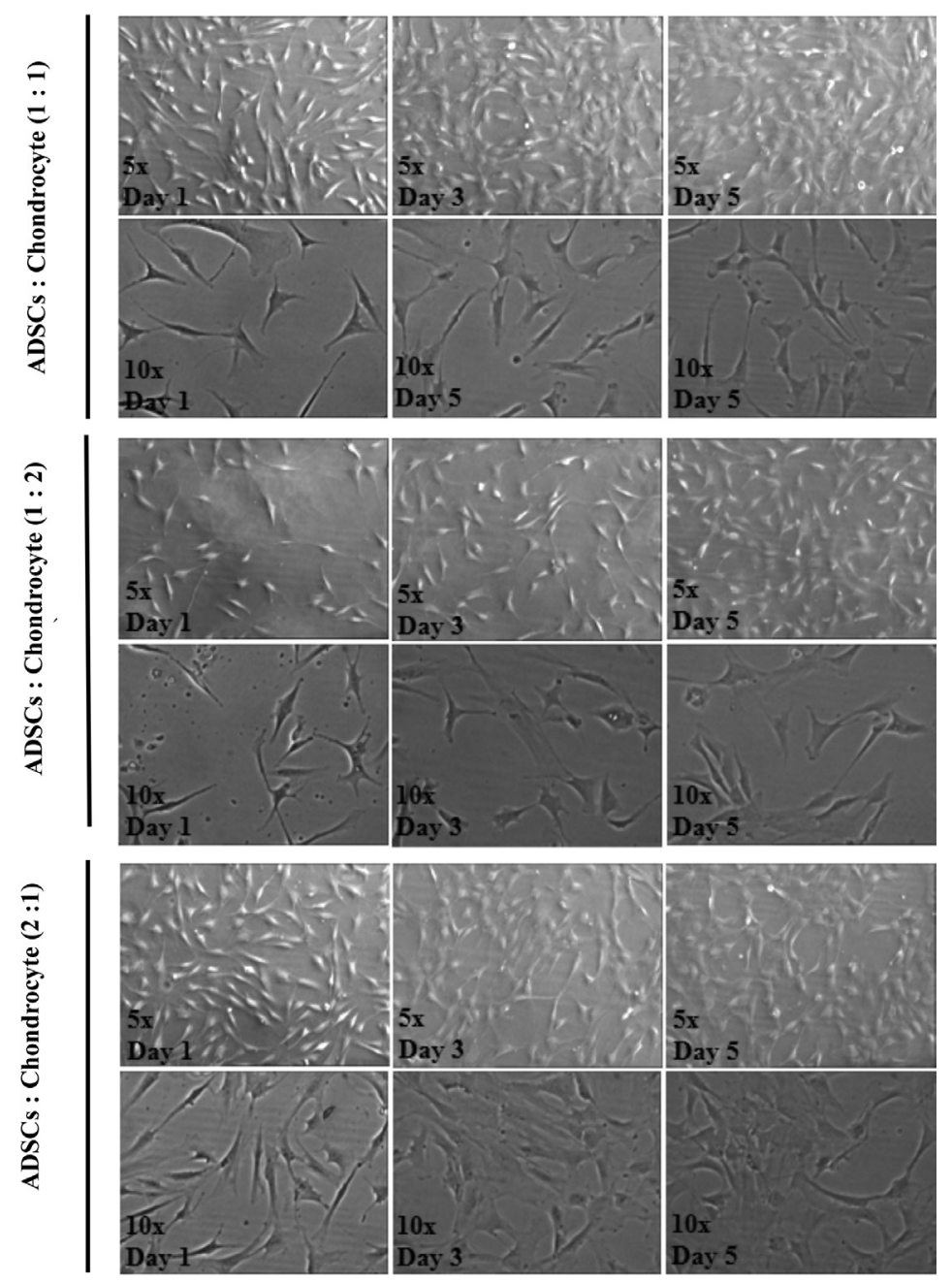

FIGURE 4. Cell morphology of ADSCs co-cultured with chondrocyte cultured at the ratio of 1:1,1:2 and 2:1 under bright field 


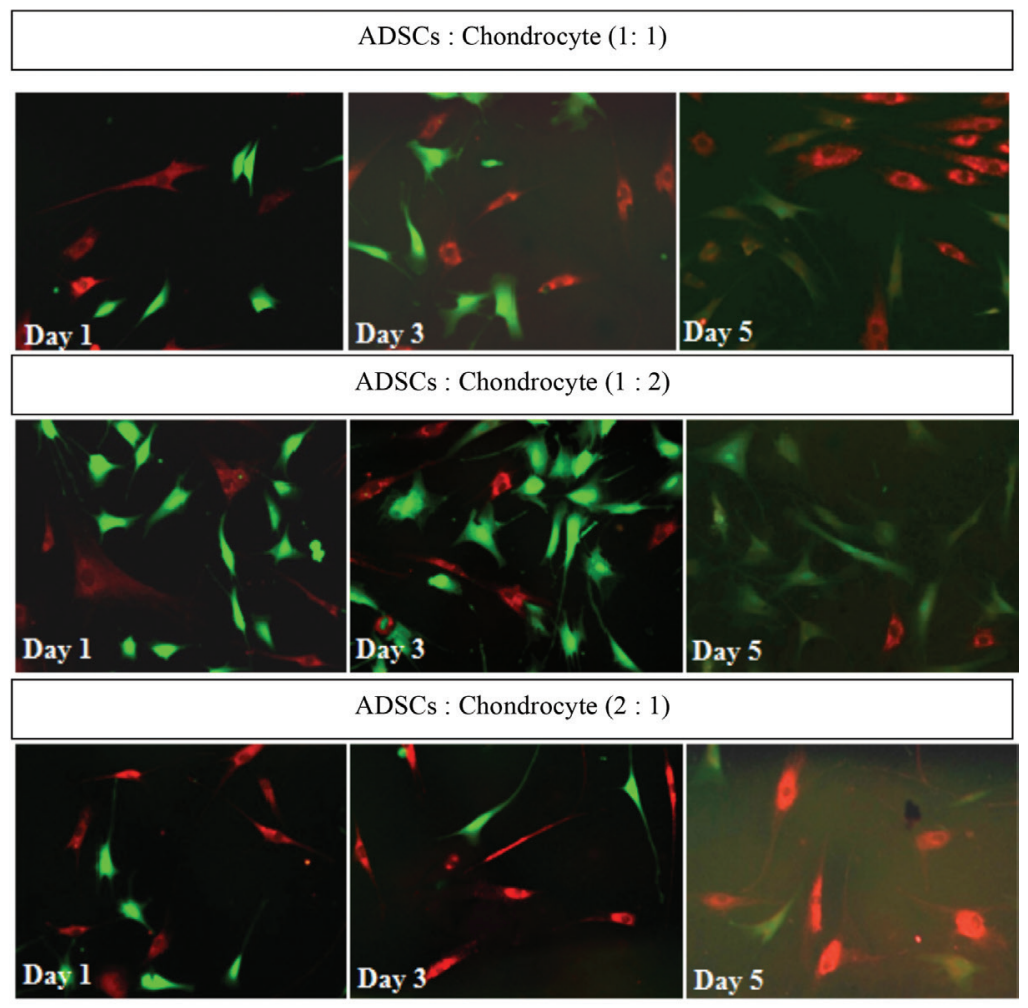

FIGURE 5. Morphological changes of cell tracker labelled of chondrocytes and adipose derived stem cells (ADSCs) with 1:1, 1:2 and 2:1 ratio observed under fluorescence microscope at day 1,3 and 5. Red: ADSCs, Green: chondrocyte

(a)

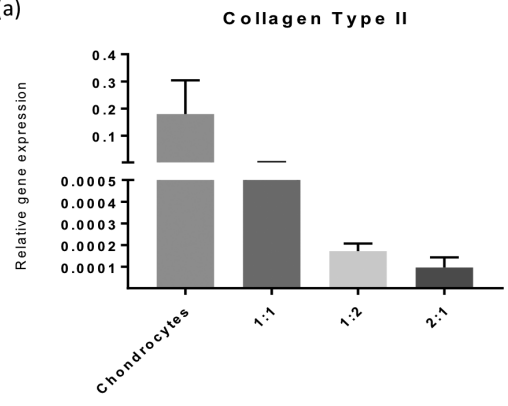

ACP

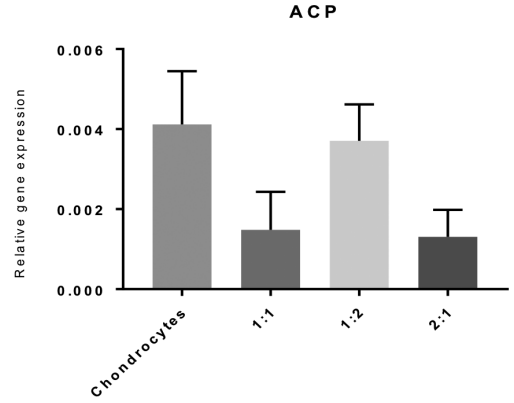

(b)

FGF.4

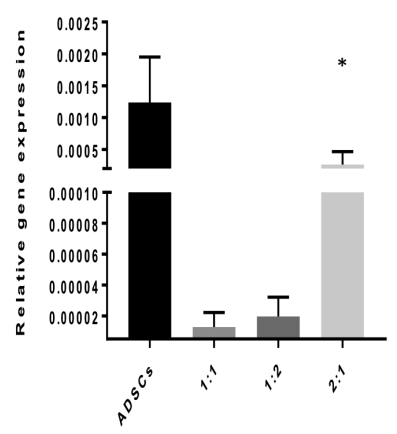

$0 c t-4$

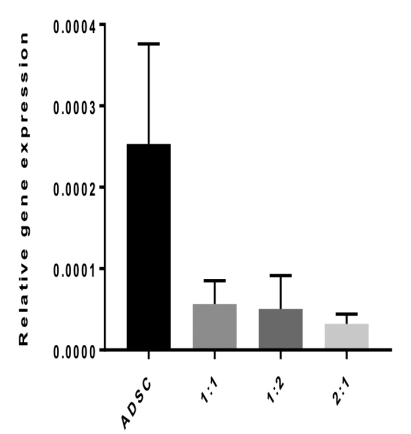

Nanog

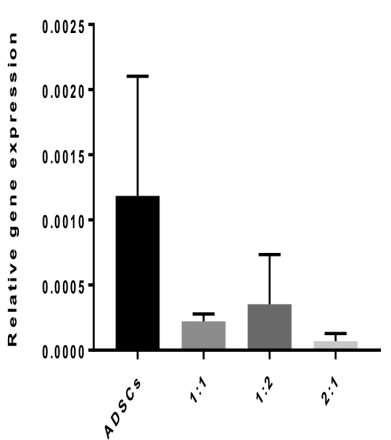

FIGURE 6. Histogram showing mRNA relative gene expression of chondrogenic and stem cell associated markers in co-culture groups of ADSCs:chondrocytes (a) Chondrogenic gene expression in co-culture groups of ADSCs: chondrocytes $(1: 1,1: 2,2: 1)$ compared with control (chondrocytes) for Collagen Type II and ACP (b) Stem cell associated gene (Nanog, Oct-4 and FGF-4) expression in co-culture groups of ADSCs: chondrocytes (1:1, 1:2,2:1) compared with control (ADSCs) (Result are presented as mean \pm standard deviation with $n=3 . *$ denotes significant difference between 2:1 group, 1:1 and 1:2 group $(p<0.05)$ 
expression might hinder the chondrogenesis of ADSCs in co-culture system.

\section{CONCLUSION}

Our data suggested that chondrogenesis of ADSCs by coculture with chondrocytes in low serum is an appropriate strategy to provide chondrogenic cells for treating cartilage lesion in the clinical setting. This in view with the cell proliferation ability of the co-culture cells, the chondrogenic differentiation evidences, serum low dependency as well as animal serum substitution with an autologous patient's serum.

\section{ACKNOWLEDGEMENTS}

This study was made possible by a grant from Faculty of Medicine, Universiti Kebangsaan Malaysia (FF-068-2013).

\section{REFERENCES}

Afizah, H., Yang, Z., Hui, J.H.P., Ouyang, H.W. \& Lee, E.H. 2007. A comparison between the chondrogenic potential of human bone marrow stem cells (BMSCs) and adipose-derived stem cells (ADSCs) taken from the same donors. Tissue Engineering 13(4): 659-666.

Anderer, U. \& Libera, J. 2002. In vitro engineering of human autogenous cartilage. Journal of Bone and Mineral Research 17(8): 1420-1429.

Bahney, C.S., Hsu, C.W., Yoo, J.U., West, J.L. \& Johnstone, B. 2011. A bioresponsive hydrogel tuned to chondrogenesis of human mesenchymal stem cells. FASEB Journal 25(5): 1486-1496.

Benya, P.D. \& Shaffer, J.D. 1982. Dedifferentiated chondrocytes reexpress the differentiated collagen phenotype when cultured in agarose gels. Cell 30: 215-224.

Breinan, H.A., Minas, T., Hsu, H.P., Nehrer, S., Sledge, C.B. \& Spector, M. 1997. Effect of cultured autologous chondrocytes on repair of chondral defects in a canine model. The Journal of Bone and Joint Surgery: American Volume 79(10): 14391451.

Brittberg, M. 1999. Autologous chondrocyte transplantation. Clinical Orthopaedic Related Research 367(Suppl): S147-S155.

Brittberg, M., Anders, L., Anders, N., Claes, O., Olle, I. \& Lars, P. 1994. Treatment of deep cartilage defects in the knee with autologous chondrocyte transplantation. The New England Journal of Medicine 331(14): 889-895.

Brunner, D., Appl, H., Pfaller, W. \& Gstraunthaler, G. 2010. Serum-free cell culture: The serum-free media interactive online database. ALTEX 27(1): 53-62.

Caplan, A.I. \& Dennis, J.E. 2006. Mesenchymal stem cells as trophic mediators. Journal of Cellular Biochemistry 98(5): 1076-1084.

Cawthorn, W.P., Scheller, E.L. \& MacDougald, O.A. 2012.Trends Endocrinology Metabolism 23(6): 270-277.

Cross, M., Smith, E., Hoy, D., Nolte, S., Ackerman, I., Fransen, M., Bridgett, L., Williams, S., Guillemin, F., Hill, C.L., Laslett, L.L., Jones, G., Cicuttini, F., Osborne, R., Vos, T., Buchbinder, R., Woolf, A. \& March, L. 2014. The global burden of hip and knee osteoarthritis: Estimates from the Global Burden of Disease 2010 study. Annals of the Rheumatic Diseases 73(7): 1323-1133.

DeLany, J.P., Floyd, Z.E., Zvonic, S., Smith, A., Gravois, A., Reiners, E., Wu, X., Kilroy, G., Lefevre, M. \& Gimble, J.M. 2005. Proteomic analysis of primary cultures of human adipose-derived stem cells: Modulation by adipogenesis. Molecular \& Cellular Proteomics 6: 731-740.

Domm, C., Schunke, M., Christesen, K. \& Kurz, B. 2002. Redifferentiation of dedifferentiated bovine articular chondrocytes in alginate culture under low oxygen tension. Osteoarthritis and Cartilage 10: 13-22.

Ferdinando, M. \& Gaetana, A.T. 2007. Concise review: No breakthroughs for human mesenchymal and embryonic stem cell culture: conditioned medium, feeder layer, or feeder-free; Medium with fetal calf serum, human serum, or enriched plasma; Serum-free, serum replacement non conditioned medium, or ad hoc formula? All glittters is not gold! Stem Cells 25(7): 1603-1609.

Fransen, M., Bridgett, L., March, L., Hoy, D., Penserga, E. \& Brooks, P. 2011. The epidemiology of osteoarthritis in Asia. International Journal of Rheumatic Diseases 2: 113-121.

Frenkel, S.R. \& Di Cesar, P.E. 1999. Degradation and repair of articular cartilage. Frontiers in Bioscience 4: D671-685.

Fuss, M., Ehlers, E.M., Russlies, M., Rohwedel, J. \& Behrens, P. 2000. Characteristics of human chondrocytes, osteoblasts and fibroblasts seeded onto a type I/III collagen sponge under different culture conditions. A light, scanning and transmission electron microscopy study. Annals of Anatomy 182: 303-310.

García-Olmo, D., García-Arranz, M., Herreros, D., Pascual, I., Peiro, C. \& Rodríguez-Montes, J.A. 2005. A phase I clinical trial of the treatment of crohn's fistula by adipose mesenchymal stem cell transplantation. Diseases of the Colon and Rectum 48(7): 1416-1423.

Goh, B.S., Che Omar, S.N., Ubaidah, M.A., Saim, L., Sulaiman, S. \& Chua, K.H. 2017. Chondrogenesis of human adipose derived stem cells for future microtia repair using co-culture technique. Acta Oto-Laryngologica 137: 432-441.

Gonzalez-Rey, E., Gonzalez, M.A., Varela, N., O’Valle, F., Hernandez-Cortes, P., Rico, L. \& Delgado, M. 2010. Human adipose-derived mesenchymal stem cells reduce inflammatory and $\mathrm{T}$ cell responses and induce regulatory $\mathrm{T}$ cells in vitro in rheumatoid arthritis. Annals of the Rheumatic Diseases 69(1): 241-248.

Grottkau, B.E. \& Lin, Y. 2013. Osteogenesis of adipose-derived stem cells. Bone Research 1(2): 133-145.

Hamid, A.A., Idrus, R.B.H., Saim, A.B., Sathappan, S. \& Chua, K.H. 2012. Characterization of human adipose-derived stem cells and expression of chondrogenic genes during induction of cartilage differentiation. Clinics 67(2): 99-106.

Hui, C.K., Kamarul, W., Wan, Z., Chin, S.S., Abu, A. \& Abdul, S. 2012. Human serum promotes the proliferation but not the stemness genes expression of human adipose-derived stem cells. Biotechnology and Bioprocess Engineering 17: 1306-1313.

Kim, S.J., Cho, H.H., Kim, Y.J., Seo, S.Y., Kim, H.N., Lee, B.J., Kim, H.J., Chung, S.J. \& Jung, S.J. 2005. Human adipose stromal cells expanded in human serum promote engraftment of human peripheral blood hematopoietic stem cells in NOD/SCID mice. Biochemical and Biophysical Research Communications 329: 25-31.

Kratchmarova, I., Kalume, D.E., Blagoev, B., Scherer, P.E., Podtelejnikov, A.V. \& Molina, H.A. 2002. A 
proteomic approach for identification of secreted proteins during the differentiation of 3T3-L1 preadipocytes to adipocytes. Molecular \& Cellular Proteomics 1: 213-222.

Liau, L.L., Makpol, S., Azurah, A.G.N. \& Chua, K.H. 2018. Human adipose-derived mesenchymal stem cells promote recovery of injured HepG2 cell line and show sign of early hepatogenic differentiation. Cytotechnology 70(4): 12211233.

Mohamad Buang, M.L., Seng, H.K., Chung, L.H., Saim, A.B. \& Idrus, R.B.H. 2012. In vitro generation of functional insulin-producing cells from lipoaspirated human adipose tissue-derived stem cells. Archives of Medical Research 43(1): 83-88.

Nejadnik, H., Hui, J.H., Feng Choong, E.P., Tai, B.C. \& Lee, E.H. 2010. Autologous bone marrow-derived mesenchymal stem cells versus autologous chondrocyte implantation. The American Journal of Sports Medicine 38(6): 1110-1116.

Riordan, N.H., Ichim, T.E., Min, W.P., Wang, H., Solano, F., Lara, F., Alfaro, M., Rodriguez, J.P., Patel, A.N., Murphy, M.P., Lee, R.R. \& Minev, B. 2009. Non-expanded adipose stromal vascular fraction cell therapy for multiple sclerosis. Journal of Translational Medicine 7: 29. https://doi.org/10.1186/14795876-7-29.

Salah, S.A., Ng, A.M.H., Aminuddin, S., Ho, C.K.C., Ismail, S., Rajesh, S., Mohd Reuzmaazran, Y., Zulkifli, M.Z. \& Ruszymah, H.I. 2013. Brief communication human adipose tissue derived stem cells as a source of smooth muscle cells in the regeneration of muscular layer of urinary bladder wall. Malays. Journal of Medical Science 20(4): 80-87.

Schnabel, M., Marlovits, S., Eckhoff, G., Fichtel, I., Gotzen, L., Vecsei, V. \& Schlegel, J. 2002. Dedifferentiation-associated changes in morphology and gene expression in primary human articular chondrocytes in cell culture. Osteoarthritis and Cartilage 10: 62-70.

Schulze-Tanzil, G. 2009. Activation and dedifferentiation of chondrocytes: Implications in cartilage injury and repair. Annals of Anatomy 191(4): 325-338.

Shahdadfar, A., Frønsdal, K., Haug, T., Reinholt, F.P. \& Brinchmann, J.E. 2005. In vitro expansion of human mesenchymal stem cells: Choice of serum is a determinant of cell proliferation, differentiation, gene expression, and transcriptome stability. Stem Cells 9: 1357-1366.

Stewart, M.C., Saunders, K.M., Burton-Wurster, N. \& Macleod, J.N. 2000. Phenotypicstability of articular chondrocytes in vitro: The effects of culture models, bone morphogenetic protein 2, and serum supplementation. Journal of Bone and Mineral Research 15: 166-174.

Tapp, H., Hanley, E.N., Patt, J.C. \& Gruber, H.E. 2009. Adiposederived stem cells: Characterization and current application in orthopaedic tissue repair. Experimental Biology and Medicine 234: 1-9.

Turner, P.A., Gurumurthy, B., Bailey, J.L., Elks, C.M. \& Janorkar, A.V. 2017. Adipogenic differentiation of human adiposederived stem cells grown as spheroids. Process Biochemistry 59: 312-320.

Valk, J. Van Der., Brunner, D., Smet, K.D., Svenningsen, Å.F., Honegger, P., Knudsen, L.E., Lindi, T., Noraberg, J., Price, A., Scarino, M.L. \& Gstraunthaler, G. 2010. Optimization of chemically defined cell culture media - Replacing fetal bovine serum in mammalian in vitro methods. Toxicology in Vitro 24(4): 1053-1063.
Valk, J. Van Der., Mellor, D., Brands, R., Fischer, R., Gruber, F. \& Gstraunthaler, G. 2004. The humane collection of fetal bovine serum and possibilities for serum-free cell and tissue culture. Toxicology in Vitro 11: 1-12.

Wang, M., Yuan, Z., Ma, N., Hao, C., Guo, W., Zou, G. \& Guo, Q. 2017. Advances and prospects in stem cells for cartilage regeneration. Stem Cells International 2017: 4130607.

Waters, H.A., Geffre, C.P., Gonzales, D.A., Grana, W.A. \& Szivek, J.A. 2013. Co-culture of adipose derived stem cells and chondrocytes with surface modifying proteins induces enhanced cartilage tissue formation. Journal of Investigative Surgery 26: 118-126.

Wessman, S.J. \& Levings, R.L. 1999. Benefits and risks due to animal serum used in cell culture production. Developments in Biologicals Standardization 99: 3-8.

Woolf, A.D. 2015. Global burden of osteoarthritis and musculoskeletal diseases. BMC Musculoskeletal Disorders 16(Suppl 1): S3. doi.10.1186/1471-2474-16-S1-S3.

Yang, Y.H., Lee, A.J. \& Barabino, G.A. 2012. Coculture-driven mesenchymal stem cell-differentiated articular chondrocytelike cells support neocartilage development. Stem Cells Translational Medicine 1: 843-854.

Zhao, Y., Jiang, H., Liu, X.W., Chen, J.T., Xiang, L.B. \& Zhou, D.P. 2015. Neurogenic differentiation from adipose-derived stem cells and application for autologous transplantation in spinal cord injury. Cell and Tissue Banking 16(3): 335-342.

Zhong, J., Guo, B., Xie, J., Deng, S., Fu, N., Lin, S., Li, G., Lin, Y. \& Cai, X. 2016. Crosstalk between adipose-derived stem cells and chondrocytes: When growth factors matter. Bone Research 4: 15036.

Zuk, P.A., Zhu, M., Ashjian, P., De Ugarte, D.A., Huang, J.I., Mizuno, H., Alfonso, Z.C., Fraser, J.K., Benhaim, P. \& Hedrick, M.H. 2002. Human adipose tissue is a source of multipotent stem cells. Molecular Biology of the Cell 12: 4279-4295

Adila A Hamid*, Satish Vaarman Jeyabalan, Aleza Omar, Nik Zattil Hanan Mohd Yasin, Wong Tzeng Lin, Liau Ling Ling \& Chua Kien Hui

Department of Physiology

Faculty of Medicine

Universiti Kebangsaan Malaysia Medical Centre

Jalan Yaacob Latiff, Bandar Tun Razak

56000 Cheras, Kuala Lumpur, Federal Territory

Malaysia

Nur Azurah Abdul Ghani

Department of Obstetrics and Gynaecology

Universiti Kebangsaan Malaysia Medical Centre

Jalan Yaacob Latiff, Bandar Tun Razak

56000 Cheras, Kuala Lumpur, Federal Territory

Malaysia

Aneeza Khairiyah Wan Hamizan

Department of Otorhinolaryngology

Universiti Kebangsaan Malaysia Medical Centre

Jalan Yaacob Latiff, Bandar Tun Razak

56000 Cheras, Kuala Lumpur, Federal Territory

Malaysia 
*Corresponding author; email: adilahamid@gmail.com

Received: 22 March 2018

Accepted: 5 June 2018 